\title{
How to Achieve Authentic Context in Classroom Oral English Teaching
}

\author{
Xiaomei Yang \\ Qingdao University of Science and Technology, Qingdao, China \\ Email: Lindateacher@tom.com
}

\begin{abstract}
Teaching oral English in traditional classroom setting is the main way conducted in China, which is artificial and not very helpful in language learning. Based on some SLA theories, this article discusses some methods to achieve authentic context in classroom oral English teaching, including ways to optimize classroom setting and classroom instruction. We hope these suggestions can give inspiration to teachers who conduct their work in a classroom.
\end{abstract}

Index Terms —oral English, authentic, classroom teaching

\section{INTRODUCTION}

No matter communicative teaching method or task-based English teaching theory, the ability to maintain natural conversation in real working or daily life setting is undoubtedly the fundamental purpose of oral English training. As far as in 1974, Dell Hymes proposed the notion of communicative competence as an alternative to Chomsky's linguistic competence. Communicative competence is the ability to talk to others in an acceptable way without improper expressions or personal and cultural offense. To achieve this goal, practice to accomplish real task in real context is essentially needed. But the fact is that in China, students have very few chances to learn English by using it in real settings, especially by speaking it to native speakers or others who don not know any Chinese, and classroom teaching remains the most popular way. Thus, how to achieve authentic context in classroom teaching is of great importance. At the same time, many language teaching experts pointed out that to find more effective way of classroom teaching is one important task in oral English study.

\section{FACTORS TO ENHANCE SLA IN INSTRUCTIONAL CONTEXT}

Ellis (1988) argued that the following factors were likely to enhance second language acquisition in instructional contexts:

Quantity of "intake"

A need to communicate

A choice on the part of learners over what is said

The performance of a range of speech act

An input rich in "extending" utterances: These are teacher utterances that pick up, elaborate, or in other ways extend the learner's contribution.

Uninhibited practice

If we take these factors into consideration when we design an oral English class, it should include the teacher' quality input, the student' active responds and the teacher' appropriate comments. At the same time, we should make the students less nervous in order to have "uninhibited practice". But due to the lack of social experience of most Chinese learners, the classroom setting is an artificial context for the students to undertake certain task or to perform some speech acts. The consequence is to de-authenticate the language intake, and the learner's tasks will be made more difficult when they occur in real context.

\section{THEORIES USED AS GUIDELINE}

Most theories come from the area of second language acquisition. For much of this century, there has been a passionate debate in Western educational contexts at least, between those who believe that the function of an educational system is the transmission of a received body of facts, values, and procedures for conceptualizing and adding to that body of knowledge, and those who believe that the function of education is to create the condition whereby learners might generate their own skills and knowledge. It is a debate between those who believe that education is a matter of making meaning for the learner on the one hand, and those who believe that the function of education is to facilitate the process whereby learners make their own meaning, on the other. Based on the notion of the latter, grew experiential learning. The following is a comparison between the traditional and experimental models. 


\begin{tabular}{|c|c|c|}
\hline Dimension & Traditional Model: behaviorism & Experiential Model: constructivism \\
\hline 1.view of learning & Transmission of knowledge & Transformation of knowledge \\
\hline 2. Power relation & Emphasis on teacher's authority & Teacher as "learner among learners" \\
\hline 3.Teachers's role & $\begin{array}{c}\text { Providing mainly frontal instruction; } \\
\text { professionalism as individual autonomy }\end{array}$ & $\begin{array}{c}\text { Facilitating learning(largely in small } \\
\text { groups); collaborative professionalism }\end{array}$ \\
\hline 4. Learner's role & $\begin{array}{c}\text { Relatively passive recipient of } \\
\text { information; mainly individual work }\end{array}$ & $\begin{array}{c}\text { Active participation, largely in } \\
\text { collaborative small groups }\end{array}$ \\
\hline 5. View of knowledge & $\begin{array}{c}\text { Presented as "certain"; application } \\
\text { problem-solving }\end{array}$ & $\begin{array}{c}\text { Construction of personal knowledge; } \\
\text { identification of problems }\end{array}$ \\
\hline 6. Control process & Mainly teacher-structured learning & Emphasis on learner; self-directed learning \\
\hline
\end{tabular}

Kohonen (1992) argues that the experiential model offers potential for a learning atmosphere of shared partnership, a common purpose, and a joint management of learning. He suggests that in classrooms infused with the vision promised by experiential learning, behavior is a joint responsibility of the whole class, and that the teacher is only one member within the class.

\section{Establishing AUthentic ORAL ENGLISH TEACHING CONTEXT}

Of course, no matter what effort we make, classroom setting can never provide students with the authentic context as in real communication environment. But still we must try to let the students feel they are really doing some task, performing speech acts in the way it should be.

\section{A. Ways to Optimize the Classroom Setting}

a) Classroom Organization

The traditional mode of classroom organization is a teacher-fronted one, with learners sitting in rows facing the teacher. The physical set-up of classroom is predicated on this mode of organization, with desks set out in rows, and in most cases, screwed to the floor, thus making any other mode of organization almost impossible. Students in such classrooms lack the chances to share ideas or negotiate meaning with each other.

Small group and pairs are better ways of classroom organization, which are backed by cooperative leaning theory. In dividing the students into different groups, factors like personality, intimacy, gender balance etc. should be taken into consideration in order to make the small group work in a harmonious way. Each group can occupy some space in the classroom, especially the four corners where there they can form a circle, or at least they can see each other's face when they speak. On some particular occasions, students may be required to stand up and move around while doing speaking tasks. By allowing students to break the classroom rule that they should remain seated in class, it also breaks the rule that they should not speak in class (Nunan, 1999).

b) Group Activities

Group activities are a good way to improve students' oral English level. In group activities, students can get comprehensible input from peers in the same group. At the same time, they can get better psychological support and develop their language ability in their cooperation (Pica, Young \& Doughty, 1987). In order to motivate all students to fully participate in the activities, when doing discussion in oral English class, one group can be sent out of the classroom. When the other groups do the presentation at last, this group is called back to listen and see if they can understand what is going on. In this way, the speaker must speak clearly in order to make themselves understood, which is in accordance with Swain's output hypothesis: adequate output can let the students pay attention to their interlanguage, and activate the inner cognitive language acquisition system. At the same time, the listeners must listen attentively to get the necessary information to give a summary and make comments. This kind activity highly authenticates the communication context, accelerating the learning process.

c) Scenario

Scenario is a kind of activity derived from role playing. Different from role playing, scenario is a problem-oriented, open-ended task similar to real life situation, focusing the students' attention on specific strategies. There is information gap between the participants, so they have to think hard before they decide what to say next. Since scenario is quite close to real life situation, the participant must pay attention to the appropriateness of their words. They must take into account of different social status, different sex, age, the social role they are playing and some other factors.

In doing the conversation, the students strongly feel that they cannot simply play a fixed role and use the expressions offered by the teacher or prepared by themselves because they are in a dynamic context. In order to fulfill the task, the participants must employ all language skills in his or her command. At the same time, scenario activities requires appropriate language use. For example, as an employee, you cannot threaten your boss although you are mad with him, which is often ignored by the students because classroom is an artificial situation. So teachers should point out the inappropriate use of language, and videos of similar real situation conversation will be a big help in developing students' communicative competence.

\section{B. Ways to Optimize Classroom Instruction}

In traditional language classroom, learners are taught chiefly about language and its rules. They learn facts about 
language rather than how to use it communicatively to express ideas, to talk and write to other people, to read and listen to real language, and to learn how to cooperate with others.

a) Low-structure Teaching

High-structure tasks are those in which teachers have all the power and control. Low-structure tasks are those in which power and control are developed to the students. Low-structure situations provide learners with numerous options and a great deal of autonomy. In oral English teaching classes, direct instruction should be integrated into instructional sequences in which learners are actively involved in using the language, guided and helped by their teachers. The teacher's primary role is the provision of pedagogical opportunities through which learners might structure and restructure their own understanding. The ultimate goal is to enable the learner to communicate with others in the world beyond the classroom where they will not have a teacher on hand. In helping learners achieve this goal, however, teachers need to redefine their approach to teaching.

b) Creative Language Use

In oral English teaching context, learners should be given structured opportunities to use the language that they have been practicing in new and unexpected ways. They should be provided with the language that they will need to take part in genuine communicative tasks, and they should be given opportunities to respond appropriately in new situations outside the classroom. Teachers should design tasks that allow learners to practice identifying the key grammar and vocabulary in real-world texts and to develop the skills of speaking and listening in an integrated way, just as in authentic communicative situations. Teachers also should pay attention to students' cooperation with other learners and with their teachers. In this way, classrooms themselves act as a bridge to the outside world rather than as a linguistic quarantine station where learners are protected from the risks involved in having to engage in genuine communication.

c) Authentic Material

In oral English teaching classroom, learners are strongly encouraged to use authentic materials. They should have access to genuine language drawn from a wide variety of contexts, including TV and radio broadcasts, conversations, discussions and meetings of all kinds, talks, and announcements. They read magazines, stories, printed material and instructions, hotel brochures and airport notices, and a wide range of other messages. This practice helps them cope successfully with genuine communication outside the classroom. Bring authentic data into the classroom can assist learners to see how grammatical forms operate in context and enable speakers to make communicative meanings. Another advantage of authentic data is that learners encounter target language items in the kinds of contexts that they naturally occur, rather than in contexts that have been concocted by a textbook writer. Ultimately, this assists the learner because he will experience the language item in interaction with other closely related grammatical and discourse elements. By distorting the contexts of use in which grammatical items occur, nonauthentic language, in some respects, actually makes the task for the language learner more difficult.

\section{Classroom Teaching Preparation and Extension}

English learning is a long-process activity, and the practice in the limited class time is far from enough. In order to make full use of the class time, the teacher should think about the difficulty and feasibility of the tasks to be carried out in the class. As to some activities mainly performed by students, like role play and simulation, the teacher and the student should exchange ideas before they do that before all the other students. Thus, some obvious mistakes can be avoided and the teacher will be more prepared to give instruction and comments. In this way, the oral English class will become more effective. Another way is to extend the class to every time and every place possible and let "every wall in the school talk". In spite of some extra curriculum activities like oral English competition, students are encouraged to use English in their dormitory and the canteen. At the same time, topics which are collected from the students' own life are welcomed to bring to the class - students are always more ready to talk about events happened around themselves, like pursuing further education and chatting on the Internet.

The cooperation between the school and society is of crucial importance. The school should grasp every chance to provide the student with opportunities to practice their English. Many students report that on-the-spot use of English greatly motivate them and let them realize their weaknesses. Social organizations also should offer some opportunities for students to work as volunteers when they are free with a little payment or even no payment.

\section{CONCLUSION}

Teaching oral English in the classroom setting is not a easy thing: many students do not feel they can speak better English after attending classes of one term or two. In spite of giving the student correct ways to learn English, oral English classes should be made full use of to construct natural and authentic environment for the student to speak English.

For a long time, the traditional classroom setting and class organization limit teacher-student interaction and many students are not motivated in class, so the low efficiency of oral English teaching is notorious in the educational field and the society. Some people resort to foreign teachers, but foreign only can provide some authentic input, and most of them are not good at teaching skills. To change this situation we should depend on ourselves and explore the potentials. Of course we cannot change all these within a short time, but we can start from what we have now and optimize the teaching environment. The above are some suggestions based on SLA theories and teaching practice. We hope these 
skills can be some help when teachers design their classes, and at the same time, we hope more researchers and teachers work on the oral English class.

\section{REFERENCES}

[1] Ellis, R. (1988). Classroom Second Language Development. London: Prentice-Hall.

[2] Hymes. D. (1974). Foundations in Sociolinguistic. Philadelphia: University of Pennsylvania Press.

[3] Kohonen, V. (1992). Experiential language learning: Second Language Learning as Cooperative Learner Education. In D. Nunan (ed.), Collaborative Language Learning and Teaching. Cambridge: Cambridge University Press.

[4] Krushen, S. (1985).The Input Hypothesis. London: Longman.

[5] Nunan D. (1999). Second Language Teaching and Learning. Heinle \&Heinle Publishers.

[6] Pica, Young \& Doughty. C, (1987) The Impact of Interaction on Comprehension. TESOL Quarterly .(21).

[7] Richards, J.C., J.Platt, and H.Weber. (1985). Longman Dictionary of Applied Linguistics. London: Longman.

[8] Swain, M. (1985).Communicative Competence: Some Roles of Comprehensible Input and Comprehensible Output in Its Development. S. Grass \&C. Madden (ed). Input in Second Language Acquisition. Rowley, MA: Newbury House.

Xiaomei Yang was born in Qingdao, China in 1975. She received her M.A. degree in linguistics from Qufu Normal University, China in 2000.

She is currently a lecturer in the College of Foreign Languages, Qingdao University of Science and Technology, Qingdao, China. Her research interests include linguistics and second language acquisition. 